\title{
Wirausahawan Muda Mandiri dengan Program Pengembangan Kewirausahaan di Universitas Jenderal Soedirman
}

\section{Independent Young Entrepreneurs with Entrepreneurship Development Program at Jenderal Sudirman University}

\author{
Triana Setyawardani ${ }^{1}$, Kusuma Widayaka ${ }^{2}$, Kusmantoro Edy Sularso ${ }^{3}$, Yusmi \\ Wakhdiati ${ }^{4}$ \\ ${ }^{1,2,4}$ Fakultas Peternakan Universitas Jenderal Soedirman, Purwokerto \\ ${ }^{3}$ Fakultas Pertanian Universitas Jenderal Soedirman, Purwokerto \\ 1trianausoed@gmail.com, ${ }^{2 k w i d a v a k a @ g m a i l . c o m, ~}{ }^{3}$ edvsularso@gmail.com, \\ 4yusminw@yahoo.com
}

Riwayat Artikel: Dikirim 18 Februari 2019; Diterima 25 November 2019; Diterbitkan 30 November 2019

\begin{abstract}
Abstrak
Program pengembangan kewirausahaan di Universitas Jenderal Soedirman bertujuan menghasilkan wirausahawan muda mandiri berbasis iptek yang dilaksanakan selama 8 bulan. Peserta adalah mahasiswa Universitas Jenderal Soedirman sebagai calon tenant. Calon wirausahan muda mandiri diseleksi dengan beberpa tahap, yaitu: 1. Seleksi tertulis, 2. Seleksi tertulis tahap 2 dan 3. seleksi wawancara. Seleksi bertujuan untuk mengetahui kemampuan, dan motivasi calon wirausaha. Hasil diperoleh dideskripsikan untuk menjaring calon wirausaha melalui ranking nilai hasil seleksi. Calon wirausaha muda dengan jumlah 59 orang pada seleksi awal dan diperoleh 6 calon wirausaha yang akan dibimbing dan dilatih untuk menjadi wirausaha muda mandiri. Keenam calon wirausaha mempunyai usaha bidang: pengolahan susu; pembuatan sabun kefir; produksi ayam geprek dan fried chiken; produksi wedang jahe; budidaya ternak kelinci dan budidaya jangkrik alas. Kegiatan bagi tenant bertujuan untuk meningkatkan ketrampilan sesuai bidang ilmu yang ditekuni yang dibimbing dan diarahkan melalui pelaksanaan program kewirausahaan. Tenant mendapatkan bimbingan dan pelatihan baik pelatihan manajerial berupa penyusunan proposal bisnis, manajemen keuangan dan pelatihan motivasi diri. Tenant mendapatkan kesempatan magang dan melakukan pemasaran. Tenant diwajibkan untuk membuat proposal bisnis, melakukan magang dan membuat laporan akhir dan mengikuti pameran dari kegiatan yang telah dilakukan. Program pengembangan kewirausahaan juga mendatangkan pakar yang kompeten dibidang ilmunya untuk memberikan pengetahuan dan worshop kepada tenant.
\end{abstract}

Kata kunci: tenant, iptek, wirausaha, mandiri

\begin{abstract}
The entrepreneurship development program at Jenderal Sudirman University aims to produce independent science-based young entrepreneurs who have been running for 8 months. Participants are Jenderal Sudirman University as tenant. Prosepctive independent young entrepreneurs are selected with several stages, namely: 1. Written selection, 2. Written selection stages 2 and 3. Interview selection. Selection aims to determine the ability, and motivation of prospective entrepreneurs. The results obtained are described to capture potential entrepreneurs through the ranking of the selection results. Prospective young entrepreneurs with a total of 59 people in the initial selection and obtained 6 prospective entrepreneurs who will be guided and trained to become independent young entrepreneurial entrepreneurs. The six prospective entrepreneurs have business fields: milk processing; kefir soap making; production of geprek and fried chicken; production of ginger drink; cultivation of rabbit and cultivation of pedestal crickets. Activities for tenants aim to improve skills in accordance with the fields of study that are guided and directed through the implementation of entrepreneurship programs. Tenant received guidance and training in both managerial training in the form of business proposals, financial management and self-motivation training. Tenant has the opportunity to intern and do marketing. Tenant is required to make a business proposal, do an internship and make a final report and attend an exbibition of activities that have been carried out. The entrepreneurship development program also brings competent experts in the field of science to provide knowledge and workshops to tenants.
\end{abstract}

Keywords : tenant, science and technology, entrepreneurship, independent 


\section{PENDAHULUAN}

Pendidikan kewirausahaan di perguruan tinggi diarahkan untuk menumbuhkan jiwa kewirausahaan, dan meningkatkan ketrampilan berwirausaha di dalam diri mahasiswa. Upaya tersebut dilakukan tidak hanya dengan menyediakan matakuliah kewirausahaan atau menyediakan bukubuku tentang kewirausahaan, namun juga dengan memberikan kesempatan kepada mahasiswa untuk berwirausaha. Dengan demikian, jiwa kewirausahaan dan ketrampilan berwirausaha mahasiswa dapat lebih terasah melalui praktik-praktik berwirausaha (learning by doing).

Universitas Jenderal Soedirman (UNSOED) memiliki lebih dari 22 ribu mahasiswa yang tersebar di 12 fakultas. Pendidikan kewirausahaan bagi mahasiswa UNSOED tersebut menjadi hal yang sangat penting dilakukan, baik secara terpadu ditingkat universitas maupun di tingkat fakultas. Pada tingkat universitas, UNSOED telah memiliki Pusat Inkubator Bisnis (PIB), sedangkan di tingkat fakultas dikelola oleh bidang kemahasiswaan dan alumni. Fakultas Peternakan UNSOED, yang memiliki mahasiswa aktif kurang lebih 1350 orang memiliki salah satu misi yang sangat relevan dengan kewirausahaan, yaitu "menyediakan sumberdaya manusia yang kompeten, profesional di bidang peternakan dan berjiwa wirausaha (entrepreneurship)". Seorang wirausaha harus memiliki karakter dasar dengan visi jelas yang menjadi dasar bagi pendorong perubahan dengan kemampuannya didalam mengkombinasikan berbagai sumber daya dengan iptek yang diperoleh dikampus untuk mendapatkan sesuatu yang baru (Rosmiati, Junias, \& Munawar, 2015). Pemerintah mendorong munculnya wirausaha muda berasal dari kampus untuk menciptakan peluang lapangan kerja dengan kemampuan teknologi sebagai latar belakang usahanya yang didasarkan pada orientasi profit ekonomi. Universitas sebagai salah satu sumber ilmu kewirausahaan melakukan pembinaan kepada tenant melalui pelatihan, pendampingan dan sejumlah kegiatan kreatif untuk menghasilkan wirausahawan muda baru yang berbasis iptek.

Dengan tumbuh dan berkembangnya jiwa kewirausahaan dikalangan mahasiswa diharapkan mampu menghasilkan lulusan yang dapat berkiprah secara global dan menjadi wirausaha, yaitu wirausaha yang yang berbasis pada Ilmu Pengetahuan dan Teknologi (IPTEK) sesuai dengan latar belakang pendidikan masing-masing. UNSOED sebagai salah satu pusat pengembangan wirausaha menjadi unit pelayanan bagi kewirausahaan yang profesional, mandiri dan berkelanjutan yang berdasarkan pada iptek dan ekonomi. Dalam upaya menumbuhkan jiwa dan ketrampilan wirausaha bagi mahasiswa, UNSOED melakukan upaya secara kelembagaan melalui (Pusat Inkubator Bisnis (PIB), Career \& Entrepreneurship Advisory Center (CEAC) dan bagian kemahasiswaan secara kurikuler (perkuliahan) dan kegiatan ekstrakurikuler di unit kegiatan mahasiswa (UKM). Pelatihan kewirausahaan meliputi kegiatan tenant dilakukan untuk memberikan motivasi, semangat berwirausaha. Para mahasiswa memiliki semangat dan kreativitas untuk berwirausaha. Untuk memotivasi mahasiswa sebagai tenant, maka dibutuhkan penyemangat yang mampu menumbuhkan keberanian dan menghadapi resiko dalam berwirausaha yang dapat diberikan oleh seorang motivator yang berpengalaman dalam berwirausaha (John dkk.,2014).

Pengelola, sarana perguruan tinggi dan kelembagaan adalah Pusat Inkubator Bisnis (PIB) sebagai salah satu wadah bagi wirausahan baru bagi mahasiwa dan dosen yang berkiprah di bidang wirausaha di UNSOED dan merupakan satu bentuk unit usaha/PPKIK yang menangani kegiatan usaha yang mempunyai potensi untuk dikembangkan dan menguntungkan. Iinkubator wirausaha diharapkan mampu memfasilitasi dan memberikan pelayanan 
dalam hal : penyediaan ruang, sarana dan prasarana, bimbingan dan konsultasi, penelitian, pengembangan usaha serta akses penggunaan teknologi, pelatihan dan peningkatan keterampilan, akses pendanaan, penciptaan jaringan (network) dan kerjasama, serta manajemen HKI (Hak Kekayaan Intelektual). Inkubator yang ada di perguruan tinggi seperti UNSOED termasuk dalam katagori University-related incubators: dibentuk dengan tujuan untuk mengkomersialisasikan ilmu, teknologi dan hak intelektual yang dihasilkan perguruan tinggi. Para wirausaha dan calon wirausaha memilki kesempatan untuk mendapatkan bimbingan, pembinaan, pelatihan, penggunaan teknologi, serta kemudahan lain dari para ahli, praktisi, serta akademisi. Selain itu di Unsoed juga terdapat wadah wirausaha bagi mahasiswa dengan nama Career and Entrepreneurship Advisory Center atau disingkat CEAC, dengan misi menjadi menjadi pusat bimbingan dan bantuan karir dan kewirausahaan yang unggul bagi mahasiswa yang berwirausaha. Tenant yang masuk dalam katagori Program Pengembangan Kewirausahaan (PPK) mempunyai keunggulan, antara lain tenant dibekali dengan ilmu pengetahuan dan teknologi sehingga produk yang dipasarkan/dijual mempunyai kesaragaman produk, kualitas dan kontinuitas terjamin. UNSOED sebagai penyelenggara PPK berperan : (1) memfasilitasi mahasiswa dan alumni kemampuan yang dibutuhkan untuk memenangkan kompetisi dalam berwirausaha; (2) membantu alumni dalam membuka usaha sendiri; memperkenalkan mahasiswa dan alumni kepada pasar kerja dan dunia wirausaha; dan (4) meningkatkan kerjasama dengan sektor swasta dan pemerintah serta dengan ikatan alumni. Tujuan pelaksanaan kegiatan program kewirausahaan adalah melakukan evalusi kegiatan yang dilakukan oleh tenant sesuai dengan bidang usaha yang dijalankan.

\section{METODE}

Metode yang dilakukan adalah deskripsi kualitatif untuk mendapatkan informasi tenant yang dibina melalui program pengembangan kewirausahaan sesuai bindang usaha yang dijalankan, antara lain pengolahan susu; pembuatan sabun kefir; produksi ayam geprek dan fried chiken; produksi wedang jahe; budidaya ternak kelinci dan budidaya jangkrik alas. Data primer diperoleh dari hasil wawancara dengan tenant dan dilengkapi dengan dokumentasi kegiatan yang dilakukan selama kegiatan dilakukan (8 bulan).

\section{Rekruitmen dan seleksi calon wirausaha}

Mahasiswa calon tenant pada seleksi pertama berjumlah 59 orang berasal dari beberapa fakultas, yaitu: fakultas peternakan, perikanan dan kelautan, pertanian, hukum dan ekonomi. Peserta didominasi oleh mahasiswa dari fakultas peternakan Unsoed sebanyak 40 orang peserta. Pola seleksi yang diterapkan dalam rekruitmen calon tenant adalah sebagai berikut:

Gambar 1.

Tahapan seleksi calon tenant

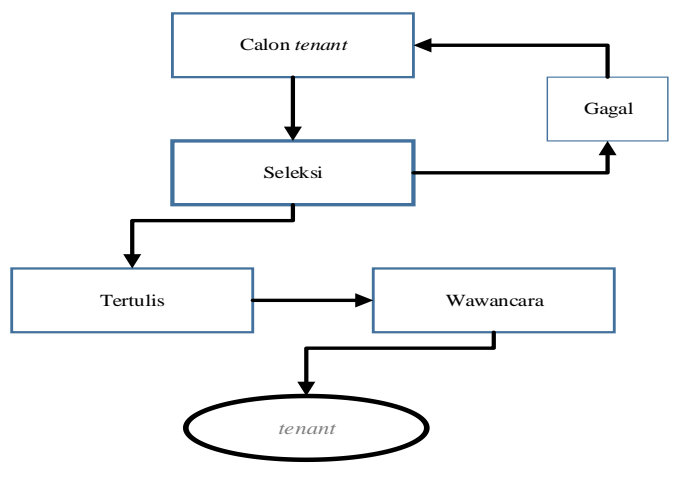


Hasil seleksi diperoleh 15 calon tenant yang diseleksi kembali sampai dengan tahapan pembuatan proposal bisnis dan akhir seleksi diperoleh 6 calon tenant yang lolos sampai dengan tahap wawancara. Seleksi tersebut dilakukan secara tertulis dan wawancara, adapun tujuan dilakukan seleksi wawancara adalah mengetahui motivasi, keseriusan dan sikap mental dalam menjadi wirausaha muda.

\section{Pelaksanaan Program}

Gambar 2.

Gambaran umum pelaksanaan kewirausahaan dalam program PPK

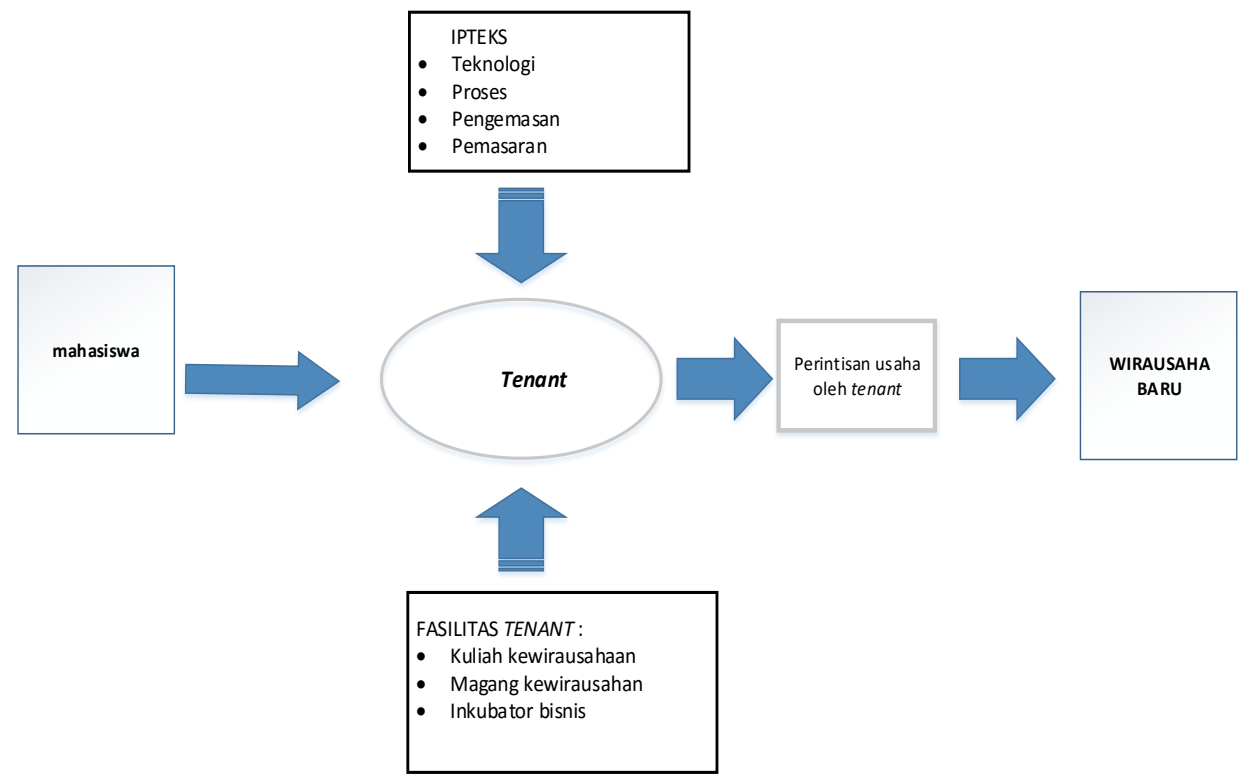

Gambaran umum pelaksanaan kegiatan untuk menciptakan wirausahawan muda mandiri sesuai penguasaan ilmu meliputi beberapa tahapan antara lain: Kuliah kewirausahaan untuk memberikan bekal berupa teori dan pengetahuan kewirausahaan muda berdasarkan iptek dan berbasis profit ekonomi. Kuliah kewirausahaan untuk tenant dilakukan selama kurun waktu tertentu dan sebagai nara sumber adalah pakar yang kompeten dibidang usaha dan ilmu yang dikuasai. Pelatihan kewirausahaan meliputi kegiatan tenant dilakukan untuk memberikan motivasi, semangat berwirausaha.

Pola bimbingan dan pengawasan terhadap tenant dilakukan oleh pengajar/tim pelaksana dan mitra. Dengan orientasi pada usaha, dimulai dari pemilihan bahan baku, cara berproduksi yang baik, pengemasan dan pemasaran. Pola bimbingan dilakukan juga dengan memberikan motivasi tenant untuk merintis usaha dengan sungguh- sungguh, membimbing dalam membuat pengembangan bisnis. Selain itu tim pelaksana juga mengawasi usaha tenant yang mulai dirintis dan apabila terdapat kendala, maka berupaya untuk mencarikan solusi bagi masalah tenant.

Pengelola program melaksanakan pengawasan terhadap jalannya seluruh program. Namun bentuk awal pengawasan terhadap tenant lebih dilakukan oleh tim pelaksana mulai dari pelatihan sampai dengan jalannya usaha baru yang dirintis. Setiap tahapan yang dilakukan oleh tenant, dalam pengawasannya tidak ditekankan pada mencari kesalahan tetapi lebih kepada pengarahan dan pembetulan kalau terjadi penyimpangan atau kesalahan.

Teknik pembiayaan diberikan kepada tenant untuk membantu usaha berdasarkan hasil kajian dan evaluasi oleh tim berupa bantuan pembiayaan. Bantuan tersebut diberikan secara bertahap bersama dengan pembimbingan dan pengontrolan serta 
didokumentasikan. Pembiayaan akan dilanjutkan apabila usaha sudah berjalan dengan baik dan berhasil serta konsisten terhadap usaha yang dijalankan, maka tenant berpeluang untuk dibiayai untuk tahap selanjutnya. Sehingga tenant dapat sebagai motivator untuk tenant pada periode berikutnya dan bisa digunakan sebagai contoh wirausaha muda. Kerjasama dengan diskusi dengan pengusaha sukses kususnya penguatan manajemen dan cara mempertahankan keberlanjutan usaha yang dilakukan.

\section{HASIL DAN PEMBAHASAN}

\section{Hasil Rekruitmen Calon Wirausaha}

Hasil kegiatan kewirausahaan memberikan pengembangan jiwa dan semangat kewirausahaan dikalangan mahasiswa. Kegiatan tersebut merupakan hal penting dan merupakan kebutuhan mendasar dalam upaya meningkatkan kualitas sumber daya manusia yang produktif, kreatif dan inovatif (Santosa, 2014).

Peserta calon tenant yang ikut dalam seleksi tahap pertama sebanyak 59 orang, selanjutnya diperoleh 6 orang tenant yang dididik melalui tahapan program kewirausahaan yang direncanakan.

\section{Tahap perkuliahan kewirausahaan}

Tenant mendapatkan kuliah kewirausahaan selama 2 minggu dengan materi perkuliahaan yang terbagi dalam 2 katagori, yaitu :

a. Perkuliahan kewirausahaan umum, meliputi: latar belakang kewirausahaan, motivasi berwirausaha, pemasaran dan perancangan bisnis

b. Perkuliahan kewirausahaan sesuai dengan bidang usaha yang ditekuni tenant, dengan mendatangkan pakar, antara lain adalah: bidang kesehatan dan pemeliharaan kelinci dan jangkrik alas; bidang produksi dan pemasaran yogurt, wedang jahe instant, ayam geprek dan sabun kefir. c. Perkuliahan tentang motivasi juga diberikan oleh pakar motivasi. Hal ini sesuai dengan pernyataan bahwa mahasiswa memiliki semangat dan kreativitas untuk berwirausaha. Untuk memotivasi mahasiswa sebagai tenant, maka dibutuhkan penyemangat yang mampu menumbuhkan keberanian dan menghadapi resiko dalam berwirausaha yang dapat diberikan oleh seorang motivator yang berpengalaman dalam berwirausaha (John, Wijaya, \& Cokki, 2014). Mata kuliah kewirausahaan yang terdiri dari materi yang disampaikan akan mempengaruhi minat berwirausaha mahasiswa peserta, tetapi cara penyampaian materi tidak mempengaruhi minat terhadap wirausaha mahasiswa (Ramadhani \& Nurnida, 2017).

d. Magang. Magang tenant dilakukan di sekitar daerah Purwokerto dan Banyumas selama tujuh hari dan dilanjutkan dengan kunjungan ke industry kecil. Magang dilakukan oleh tenant dan telah mendapatkan kuliah kewirausahan. Selama magang tenant dapat menyerap pengetahuan dan pengalaman yang ada industri produk sesuai dengan minat tenant. Selama magang tenant dapat belajar mengenai barbagai hal yang berkaitan dengan produksi, penyimpanan dan pemasaran (Oswari, 2005). Mahasiwa tidak hanya mendapatkan Pendidikan kewirausahaan di perguruan tinggi tetapi harus terjun langsung ke dunia wirausaha dan bergabung dengan orang-orang yang berkecimpung di dunia usaha sehingga mental wirausaha akan terbentuk dari pengalaman bersama (Hasni, 2018).

e. Usaha yang dijalankan oleh tenant sesuai dengan latar belakang pendidikan dan penguasaan iptek, yaitu: 
i) Usaha pengolahan susu menjadi yogurt

Usaha yogurt sudah dilakukan oleh tenant sebelum bergabung dengan program pengembangan kewirausahaan. Yogurt yang dijual dalam bentuk cup dan es lilin. Setelah bergabung maka diversifikasi yogurt dijual dalam bentuk pudding dan es campur yogurt.

ii) Budidaya jangkrik alas

Tenant semula hanya ikut membantu usaha budidaya jangkrik alas kepunyaan orang lain. Tenant akhirnya mempunyai usaha jangkrik alas secara mandiri dan telah mempunya kendang dan melakukan budidaya sendiri.

iii) Usaha ayam geprek

Tenant menjalankan usaha ayam geprek sebagai usaha pemula dan dikerjakan sampai sekarang telah menghasilkan omset cukup besar iv) Usaha pembuatan sabun kefir

Tenant menjalankan usaha produksi dan pemasaran sabun kefir yang sudah berjalan dengan baik. Pemasaran dilakukan melalui media sosial dan penawaran langsung.

v) Usaha pembuatan minuman jahe Produksi dan pemasaran minuman jahe oleh tenant merupakan usaha lanjutan yang sudah diusahakan oleh keluarga. Produk minuman jahe saat ini belum mempunyai ijin usaha produksi yang ber PIRT (Produk Industri Rumah Tangga) sehingga sedang diusahakan ijin tersebut.

vi) Usaha budidaya ternak kelinci.

Tenant telah berpengalaman dalam beternak kelinci dan jaringan pemasaran untuk ternak kelinci.

Gambar 3.

Jenis usaha tenant

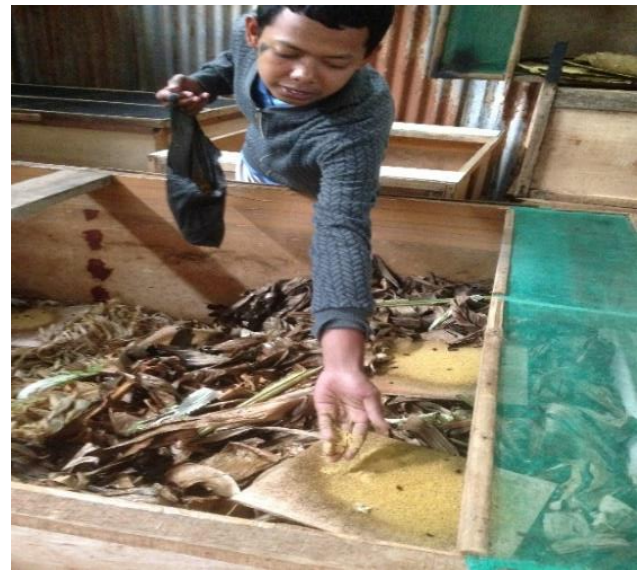

a. Jangkrik Alas

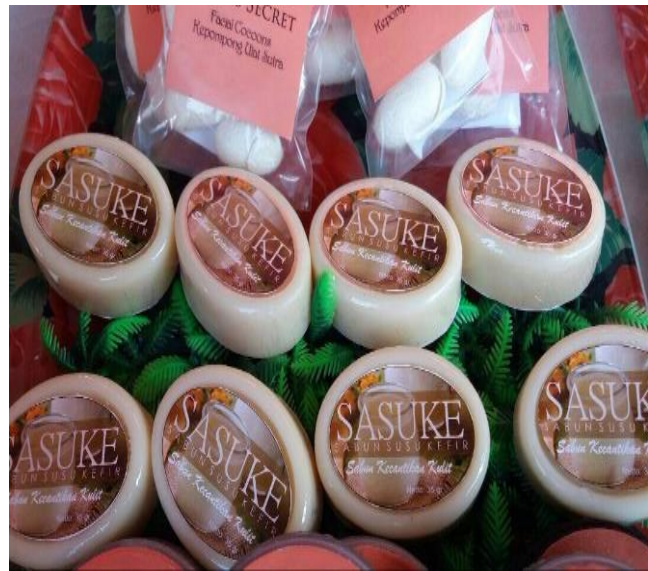

b. Sabun Kefir 


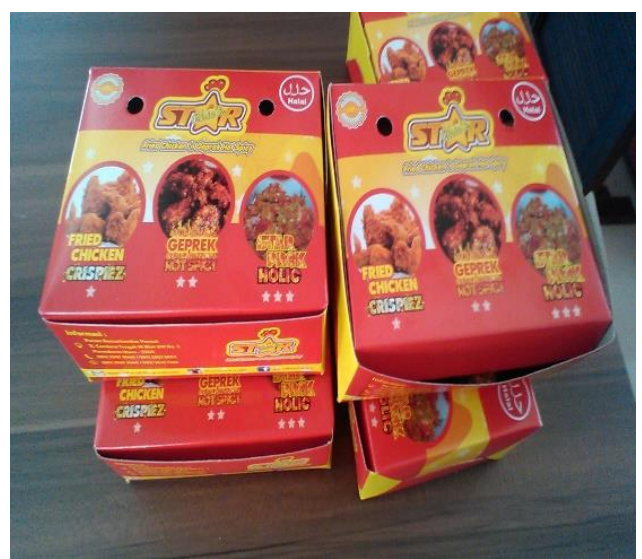

c. Fried Chicken

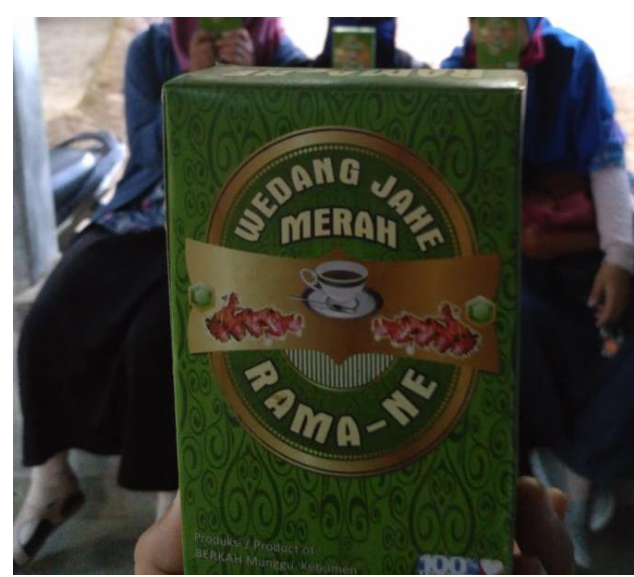

e. Minuman Jahe Instant

f. Pengenalan produk dan pemasaran Produk yang dihasilkan oleh tenant kemudian dilakukan uji coba pemasaran, melalui pemasaran secara on line; mengikuti pemasaran setiap hari minggu yaitu pada pemasaran Sunday morning (sanmor); menawarkan ke konsumen secara langsung dan menggunakan even pameran yang diselenggarakan oleh pihak universitas. Konsep berwirausaha didasarkan pada basis teknologi yang dijadikan alat berwirausaha, dengan munculnya aplikasi online, bisnis security sistem yang akan membantu tenant untuk melakukan pemasaran lebih aman dengan aplikasi mudah (Marti'ah, 2017).

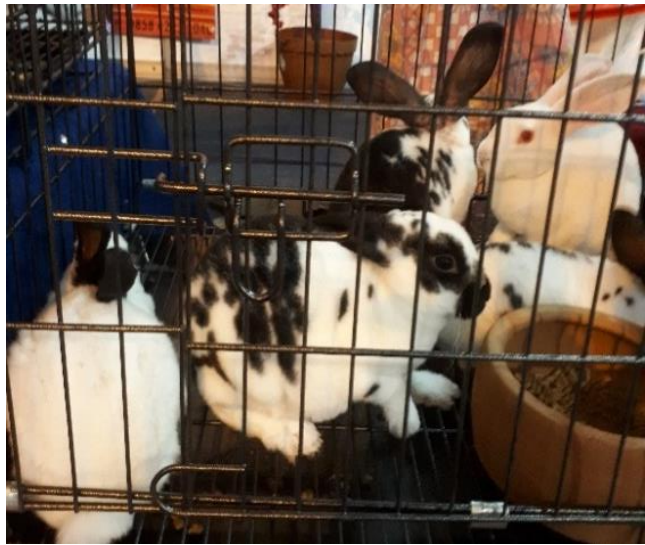

d. Kelinci Hias

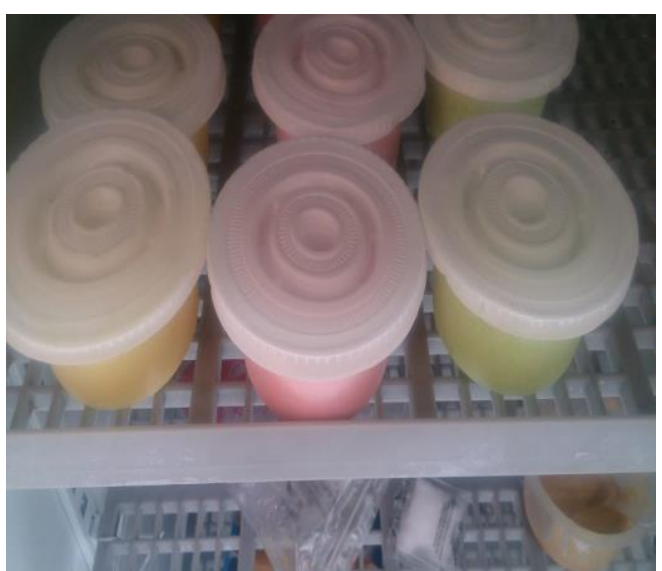

f. Yogurt

\section{KESIMPULAN}

Program ini mampu menumbuhkan kreativitas dan kemandirian bagi wirausaha muda yang dibina melalui program tersebut dan program pengembangan kewirausahaan telah menghasilkan enam wirausahawan muda mandiri dengan enam bidang usaha yang berbeda.

\section{UCAPAN TERIMAKASIH}

Terimakasih disampaikan kepada Menristekdikti atas dana kompetisi Nasional Program Pengembangan Kewirausahaan tahun 2018

\section{DAFTAR PUSTAKA}

Hasni. (2018). Urgensi Pendidikan Kewirausahaan dalam Menghasilkan Wirausahawan Muda dari Perguruan Tinggi. Expose, 17(2), 653-664. 
John, E., Wijaya, O., \& Cokki. (2014). Pengaruh Motivasi Dan Mental Terbadap Minat Berwirausaba Mahasiswa Fakultas Ekonomi Universitas Tarumanagara Jakarta. Paper presented at the Seminar Nasional Kewirausahaan Dan Inovasi Bisnis IV, Jakarta.

Marti'ah, S. (2017). Kewirausahaan Berbasis Teknologi (Technopreneurship) dalam Perspektif Ilmu Pendidikan. Jurnal Ilmiah Edutic, 3(2), 75-82.

Oswari, T. (2005). Membangun Jiwa Kewirausahaan (Entrepreneurship) Menjadi Mabasiswa Pengusaba (Entrepreneur Student) Sebagai Modal Untuk Menjadi Pelaku Usaha Baru. . Paper presented at the Proceeding. Seminar Nasional PESAT, Jakarta.

Ramadhani, N. T., \& Nurnida, I. (2017). Pengaruh Mata Kuliah Kewirausahaan Terhadap Minat Berwirausaha Mahasiswa. Ecodemica, 1(1), 89-97.

Rosmiati, Junias, D. T. S., \& Munawar. (2015). Sikap, Motivasi, Dan Minat Berwirausaha Mahasiswa. JMK, 17(1), 21-30. doi: DOI: 10.9744

Santosa, I. (2014). Masalah Dan Tantangan Pengembangan Kewirausahaan Pada Kalangan Mahasiswa Di Indonesia. Jurnal Inovasi dan Kewirausahaan, 3(3), 203-207. 